\title{
Therapeutic prospects of microRNAs in cancer treatment through nanotechnology
}

\author{
Rajendra Awasthi ${ }^{1}$ (1) \& MichaelJohn Rathbone ${ }^{2,3}$ \& Philip MichaelHansbro ${ }^{4}$ \& \\ Mary Bebawy ${ }^{3}$ \& Kamal Dua ${ }^{3,4}$
}

\# Controlled Release Society 2017

\begin{abstract}
MicroRNAs (miRNAs) represent a new class of diagnostic and prognostic biomarker as well as new therapeutic targets in cancer therapy. miRNAs are gaining significant interest due to extensive advancements in knowledge since their discovery and, more recently, their translational application as therapeutic moieties and targets in the management of disease. miRNAs used in the treatment of cancer would position them as a new class of emerging therapeutic agents. Indeed, numerous candidate miRNAs have been identified as having therapeutic application in the treatment of cancer, but there is still much to learn about how to transform these into effective, patient-compliant, and targeted drug delivery systems. In this mini review, we discuss the utility and potential of nanotechnology in miRNA formulation and delivery with particular emphasis on cancer, including their role in conferring multidrug resistance and metastatic capacity. This review benefits both the formulation and biological scientists in understanding and exploring the new vistas of miRNA delivery using nanotechnology in the cancer clinically.
\end{abstract}

\footnotetext{
* Mary Bebawy

Mary.Bebawy@uts.edu.au

* Kamal Dua

Kamal.Dua@uts.edu.au

1 NKBR College of Pharmacy and Research Centre, Meerut, Uttar Pradesh 45206, India

2 ULTI Pharmaceuticals, Hamilton 3204, New Zealand

3 Discipline of Pharmacy, Graduate School of Health, University of Technology Sydney, Sydney, NSW, Australia

4 School of Biomedical Sciences and Pharmacy, Hunter Medical Research Institute, University of Newcastle, Callaghan 2308, Australia
}

Keywords Cancer $\cdot$ Extracellular vesicles $\cdot$ MicroRNA . Microparticles $\cdot$ Nanotechnology $\cdot$ Multidrug resistance . Metastasis $\cdot P$-Glycoprotein

Introduction-role of miRNAs in regulating disease

MicroRNAs (miRNAs) were initially identified in Caenorhabditis elegans in 1993, as small non-coding RNAs, which modulate eukaryotic gene expression at posttranscriptional levels. Lee et al. first reported that the lin-4 gene was involved in larval development of Caenorhabditis elegans [1]. miRNAs play an important role in various physiological and pathological conditions including embryonic differentiation, viral infection, cardiac hypertrophy, hematopoiesis, and oncogenesis. miRNAs control a wide variety of cellular processes, such as proliferation, cell death, differentiation, motility, and invasiveness. [2, 3].

Different biological and physicochemical factors govern the effective delivery of miRNAs (Fig. 1). Delivery can be improved through various approaches such as $[4,5]$

1. minimization of degradation and elimination of miRNAs by optimization of particle size, surface charge, and chemical modification;

2. use of targeting ligands and cell-penetrating moieties to improve the tissue permeation; and

3. use of fusogenic peptides to avoid intracellular disposition of the miRNAs.

miRNA-based therapeutics represent one of the major commercial areas of interest in today's biotechnology market [6]. miRNAs are well-identified and associated in various disease pathologies such as is the case for miR-208 in heart 


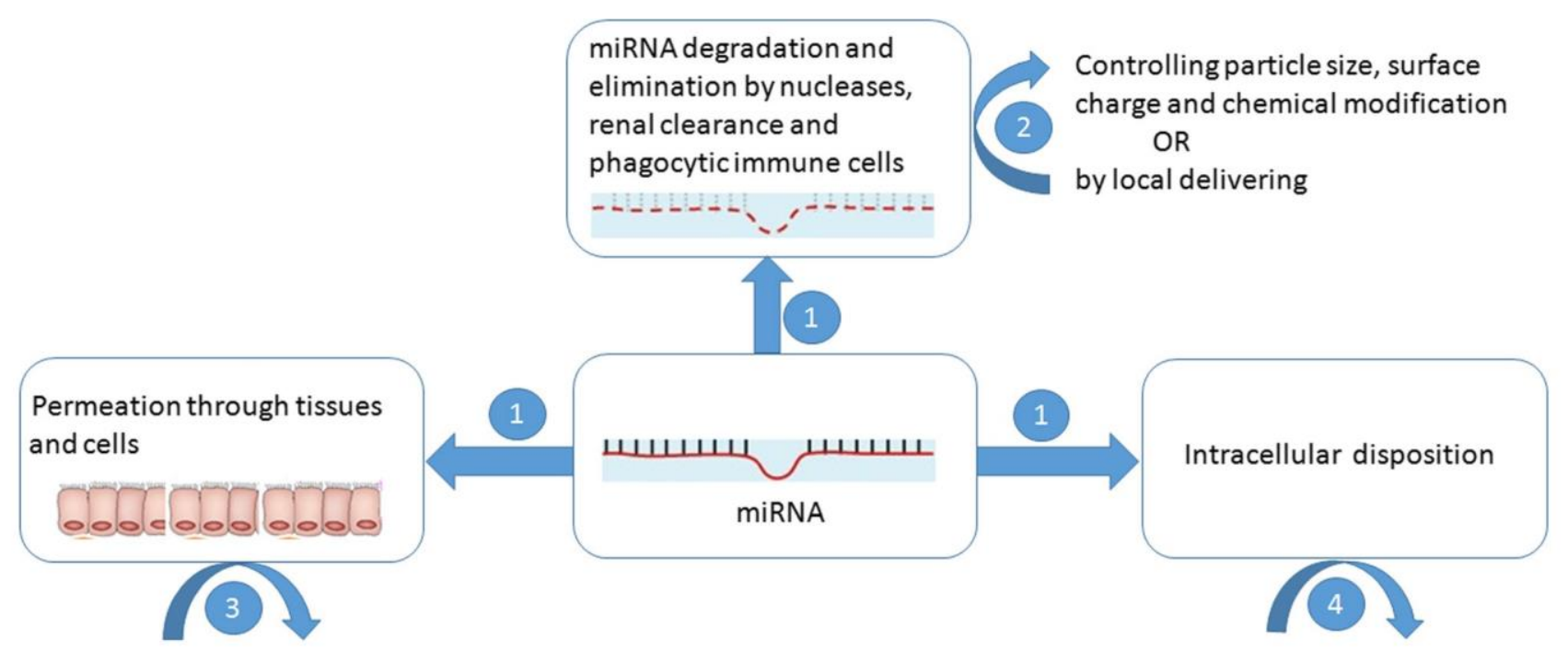

Achieved by employing targeting ligands and cell penetrating moieties

Avoided by using fusogenic peptides

Fig. 1 Challenges (1) and solutions (2-4) for effective delivery of miRNAs

failure [7], miR-15/195 in post-myocardial infarction remodeling [8], miR-145 in vascular disease [9], miR-451 in myeloproliferative disease [10], miR-29 in pathological fibrosis [11], miR34 and let-7 in cancer [12], and miR122 in liver transplant [13].

Roy and Sen [6] first demonstrated that miRNAs regulate the cellular redox environment via a NADPH oxidasedependent mechanism in human microvascular endothelial cells. They demonstrated that the hypoxia-sensitive miR$200 \mathrm{~b}$ was involved in the induction of angiogenesis by directly targeting Erythroblastosis virus E26 oncogene homolog 1 (Ets-1) in human microvascular endothelial cells. These studies lend support to the potential role of miRNAs in wound healing and angiogenesis. miRNAs block translation of messenger RNAs (mRNAs) or repress the synthesis of protein via mRNA destabilization $[5,6]$. They also serve a fundamental role during the development of the organism, through effects on cell differentiation and metabolism [14]. In 2000, a second miRNA (let-7) was identified from Caenorhabditis elegans and characterized as a 21-nucleotide small RNA [15]. Since these early studies, it is now known that more than $60 \%$ of human protein-coding genes are regulated by miRNAs [16]. The miRBase database provides a searchable online repository for published miRNA sequences and associated annotation [14]. The miRBase database contains more than 28,645 hairpin precursors and more than 35,828 mature miRNA sequences in 223 species (Release 21) [17].

Hebert et al. observed that a small number of miRNAs have altered expression levels in patients with Alzheimer's disease [18]. Caporali and Emanueli reviewed the role of miRNAs in angiogenesis focusing on post-ischemicneo-vascularization [19]. Using locked nucleic acid, anti-miRNA21 oligonucleotides, bimodal imaging vectors, and neural precursor cells
(NPC) expressing a secretable variant of the cytotoxic agent tumor necrosis factor-related apoptosis-inducing ligand (STRAIL), the combined suppression of miRNA21 and NPCS-TRAIL leads to a synergistic increase in caspase activity and significantly decreased cell viability in human glioma cells in vitro [20]. In a recent report, Hsu et al. found that influenza A virus infections lead to increased inflammatory and antiviral responses in primary bronchial epithelial cells from healthy non-smoking and smoking subjects. The authors reported increased expression of miR-125a or miR-125b due to influenza Avirus infection, which reduced the expression of A20 (TNFAIP3), a negative regulator of NF-KB-mediated inflammatory responses, and mitochondrial antiviral signaling. This leads to the exaggeration of inflammation and impaired antiviral responses [21]. miRNAs also play an important role in autism spectrum disorder, and recent findings associate the condition with genetic variants in miRNA genes, miRNA biogenesis genes, and miRNA targets [22].

Calin et al. evaluated the miRNA expression profiles in chronic lymphocytic leukemia samples. They identified germ-line mutations in the miR-16-1-miR-15a primary precursor, which caused low levels of miRNA expression in vitro and in vivo and was associated with the deletion of the normal allele [23]. In a recent study, Zhao et al. found that the downregulation of miR-493-5p in hepatocellular carcinoma was correlated with tumor size, tumor differentiation, grade, and tumor/node/metastasis stage of hepatocellular carcinoma patients. The authors reported that the miR-493-5p was downregulated in hepatocellular carcinoma. This miRNA acts to suppress the proliferation of hepatocellular carcinoma cells via targeting Golgiprotein73 [24]. Sun et al. observed the upregulation of miRNA 223 in colorectal cancer tissues and the downregulation of RAS p21GTPase-activating 
protein 1 (RASA1) in colorectal cancer tissues. The in vivo xenograft model of colorectal cancer suggested that the upregulation of miR-223 could promote tumor growth and that the inhibition of miR-223 might prevent solid tumor growth [25].

\section{Description of miRNA biogenesis and regulation}

The regulation of eukaryotic gene expression is based on the cytoplasmic control of mRNA translation and degradation. The regulation of miRNAs is referred to as RNA interference (RNAi) or RNA silencing [26]. miRNAs are generated through the cleavage of primary miRNA (pri-miRNA), which incorporates into the effector complex RNA-induced silencing complex (RISC) [27]. The presence of a single (or multiple) imperfect hairpin structure(s) with a stem of approximately $33 \mathrm{bp}$ is the characteristic feature of a pri-miRNA [19].

In brief, the miRNAs are first transcribed into pri-miRNAs in the presence of polymerase II or polymerase III. In the presence of the RNAse III enzyme, Drosha, the synthesis of pri-miRNAs begins in the nucleus. In complex with other proteins (double-stranded RNA-binding domain protein called Pasha in Drosophila or DGCR8 in mammals), the primiRNAs convert into precursor miRNAs (pre-miRNAs). PremiRNAs are transported into the cytoplasm by exportin-5, a RanGTP-dependent dsRNA-binding protein, and are subsequently processed by Dicer (a cytoplasmic endonuclease RNAse III enzyme) that generates a miRNA duplex [25].

The mature duplex miRNA is then incorporated into the RNA-induced silencing complex, a ribonucleoprotein effector containing a catalytic endonuclease core (Argonaute2); Dicer, a dsRNA-binding protein-transactivating response RNAbinding protein; and a protein activator kinase $\mathrm{R}$ [28]. The process of miRNA biogenesis is presented in Fig. 2. Circulating miRNAs are released into the blood, and their expression level is specifically related to disease stage. Circulating miRNAs are considerably stable and can be easily evaluated through blood sampling and following molecular analysis [31]. A single miRNA molecule can target multiple mRNAs [32]. miRNAs have attracted wide attention by both the biological and formulation scientists due to their unique functional significance and mode of action [33].

\section{Nanotechnology in cancer therapy}

In recent years, extensive efforts have been focused on the development of nanocarriers that exhibit high delivery efficiency for miRNAs in various diseased conditions [34]. The first polymer-drug nanoconjugate system was reported by Jatzkewitz in the 1950s [35]. In contribution to the field, Bangham discovered the first liposomal formulation in mid1960s [36, 37] and Scheffel and coworkers developed the first albumin-based paclitaxel nanoparticles (Abraxane) in 1972 [38]. Abraxane was approved by the US Food and Drug Administration in 2005 for the treatment of breast cancer [39]. Table 1 provides a brief description of the various nanoformulations and their approval status.

An ideal nanoparticulate drug carrier system is one which displays prolonged systemic circulation time, is present at appropriate concentrations at the target site, retains its therapeutic efficacy against physiological barriers, and finally is metabolized in the body. To fulfill all of these properties, an ideal drug carrier system should possess physical properties of small size, high drug encapsulation efficacy, efficient localization of the carriers by tumor cells (effective binding to the specific targets through the ligands), prolonged circulation time, and finally controlled release of drug at the target site $[46,47]$.

Systemic circulation time, biodistribution, and cellular internalization of nanoparticles depend on particle size and surface properties such as surface charge. Nanoparticles accumulate in the spleen due to filtration and are removed by the reticulo-endothelial system. The optimum particle size of nanocarriers is in the range of 100 to $200 \mathrm{~nm}$ as this is ideal for enhanced permeability and retention in tumor cells [47]. This size range avoids filtration in the spleen and is large enough to avoid the uptake in the liver [47]. Nanoparticles may be opsonized and thus be recognized and eliminated by macrophages. Opsonization is the key factor that determines the fate of nanoparticles to a large extent in blood circulation. The circulation time of nanoparticles can be altered by modifying their surface charge [47]. An increased cellular uptake of nanoparticles with cationic surfaces has been reported by Chen et al. [48]. It has been established that due to the large effective surface area-volume ratio and higher particle concentrations, the nanoparticulate drug carrier systems can maintain the drug concentration at the target site within the desired level $[46,47]$. Accumulation of nanoparticles at target sites can be increased selectively by engineering the particle surface with polymer selection and coupling of targeting ligands. Cellular uptake and drug release profiles from nanocarriers are mainly dependent on the particle shape. Champion et al. reported a zero-order release profile from hemi-spherical nanoparticles [49]. Figure 3 represents a schematic presentation of a multifunctional nanocarrier. Various nanotechnology-based drug products for cancer therapy under different phases of clinical investigations are presented in Table 2.

\section{miRNA delivery through nanoparticles}

Nanotechnology is one of the principal areas which can be used to effectively formulate the delivery of miRNAs due to their small size and low molecular weight [69]. When miRNAs are attached to the surface of nanoparticles, the 


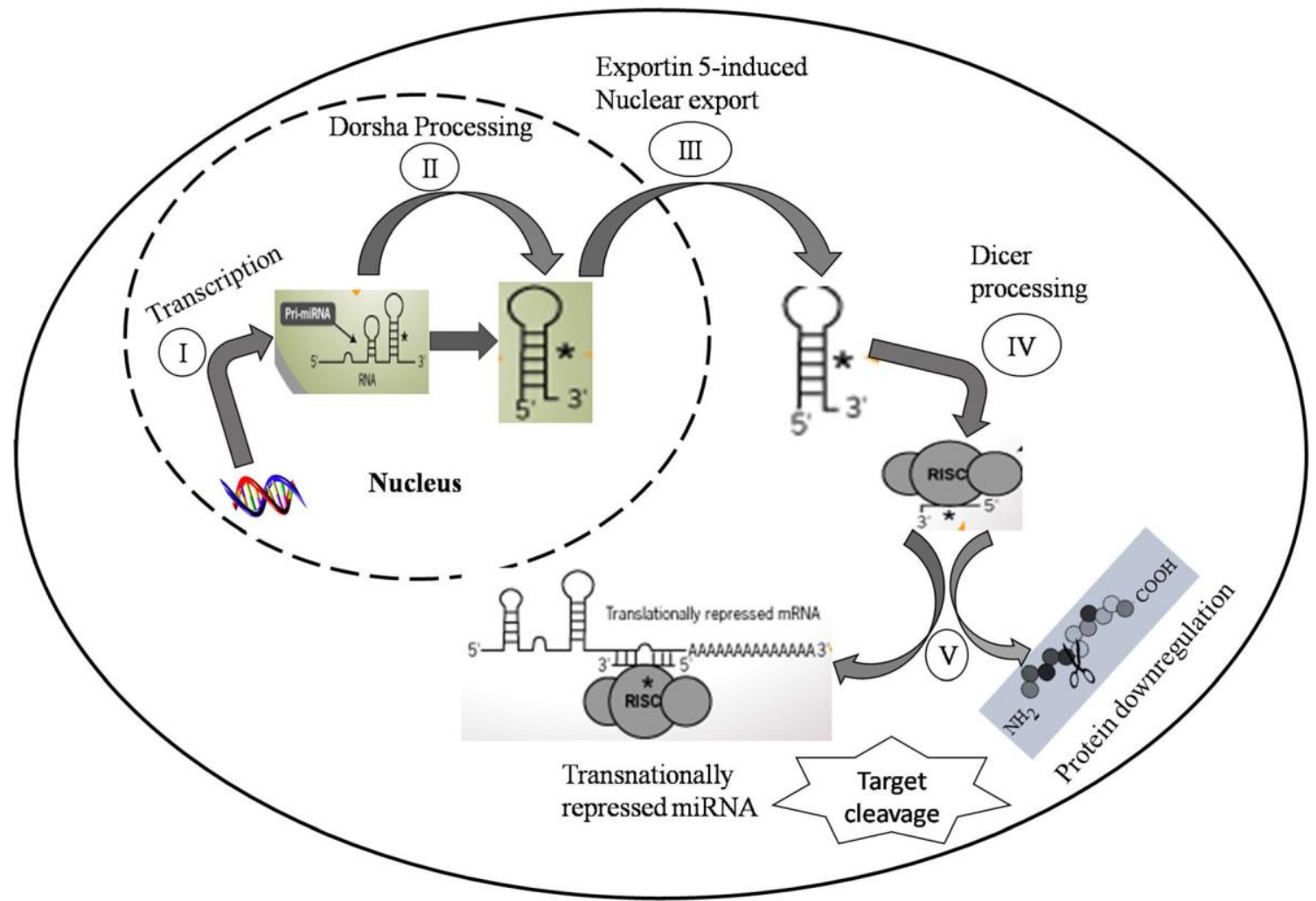

Fig. 2 The process of miRNA biogenesis. miRNA genesis initiates in the nucleus. (I) In the presence of RNA polymerase II, miRNA genes are transcribed and produce pri-miRs. (II) Pri-miRNAs are catalyzed by Drosha to produce pre-miRNAs. (III) After nuclear export to the cytoplasm, Dicer processes pre-miRNAs into 20-bp miR:miR duplexes. After

delivery efficacy of miRNA-conjugated nanoparticles increases relative to free miRNA [70].

Recently, Kato et al. reported bone morphogenetic protein 2 displays a higher osteogenic effect on MC3T3-E1 cells grown on titanium with nanotopography compared with control titanium [71]. Antonellis et al. developed miRNA-199b$5 p$-encapsulated stable nucleic acid lipid particles, and a significant impairment of Hes-1 protein levels and cancer stem cell markers in a range of different tumorigenic cell lines (colon, breast, prostate, glioblastoma, and medulloblastoma) was observed [72]. Yoo et al. demonstrated the inhibition of mature miRNA in a metastatic breast cancer cell line using novel layered gadolinium hydroxychloride nanoparticles. Specifically, anti-miRNA oligonucleotides delivered with layered gadolinium hydroxychloride nanoparticles remained functional by inducing changes in the expression of its downstream effect or/and by curbing the invasive properties. Layered gadolinium hydroxychloride nanoparticles provide a promising multifunctional platform for miRNA therapeutics by virtue of their diagnostic, imaging, and therapeutic capabilities. These nanoparticles had shown good cellular uptake profile [73]. Chen et al. developed polycation-hyaluronic acid-loaded nanoparticles containing single-chain antibody fragments for systemic delivery of miRNAs into the lung
miRNA duplex unwinding initiated by the Dicer, one strand is selected to function as mature miR and loaded into the RNA-induced silencing complex (RISC). (V) The mature miRNA leads to mRNA translational repression, as well as protein downregulation (Adapted from [5, 29, 30])

metastasis of murine B16F10 melanoma. miRNAs delivered by fabricated nanoparticles significantly downregulated the survivin expression in metastatic tumors and reduced tumor load in the lung [74].

A robust method for delivering miRNAs into cells using cysteamine-functionalized gold nanoparticles was developed by Ghosh et al. The preparation was validated on the basis of the highest payload, the lowest toxicity, efficient uptake, the fastest endosomal escape, and increased half-lives using two different tumor models [75].

The first report on a silica nanoparticle-based delivery system for miRNA delivery to neuroblastoma tumors in a murine orthotopic xenograft model was demonstrated by Tivnan et al. These carriers resulted in a decrease in tumor growth, increase in apoptosis, and a reduction in tumor vascularization [76]. Polycationic liposome-hyaluronic acid nanoparticles for the delivery of miRNA have also been reported by several investigators [77]. Systemic delivery of anti-miR-155 peptide nucleic acids using polylactic-co-glycolic acid (PLGA) polymer nanoparticles showed enhanced delivery efficiency and achieved therapeutic effects. The surface of the nanoparticles was modified with penetration, a cell-penetrating peptide [78]. Liu et al. [79] reported PEGylated liposome-polycationhyaluronic acid nanoparticle formulation modified with cyclic 
Drug Deliv. and Transl. Res.

Table 1 Nanoformulations investigated for cancer therapy and their approval status

\begin{tabular}{|c|c|c|c|}
\hline Nanoformulation & Brief description & Product approval status & Ref. \\
\hline Liposome & $\begin{array}{l}\text { Self-assembling vesicles synthesized } \\
\text { by the dispersion of phospholipids } \\
\text { with hydrophilic heads and hydrophobic } \\
\text { anionic/cationic long-chain tails }\end{array}$ & $\begin{array}{l}\text { - Doxil@ (liposomal doxorubicin) } \\
\text { approved by FDA for the treatment } \\
\text { of Kaposi's sarcoma }\end{array}$ & [40] \\
\hline Polymeric nanoparticles & $\begin{array}{l}\text { Polymeric nanoparticles synthesized by } \\
\text { self-assembly of block co-polymers } \\
\text { consisting of two or more polymer } \\
\text { chains with different hydrophobicity }\end{array}$ & $\begin{array}{l}\text { - Abraxane (albumin-bound paclitaxel) } \\
\text { is the first polymeric nanoparticle } \\
\text { formulation approved by FDA in } 2005 \\
\text { for the treatment of metastatic breast } \\
\text { cancer and and non-small-cell lung carcinoma. } \\
\text { - Livatag (doxorubicin transdug) is a } \\
\text { poly(isohexyl cyanoacrylate) } \\
\text { nanoparticle formulation approved } \\
\text { for the treatment of multidrug-resistant } \\
\text { (MDR) protein-overexpressing hepatocellular carcinoma. } \\
\text { - Genexol-PMTM (paclitaxel-encapsulating } \\
\text { PLGA- } b \text {-methoxyPEGnanoparticles) } \\
\text { has received regulatory approval in South Korea. } \\
\text { Currently, it is undergoing phase II } \\
\text { clinical trials in the USA. } \\
\text { - BA-003 (doxorubicin transdrug, Livitag)- } \\
\text { polyisohexylcryano-acrylate-containing } \\
\text { doxorubicin under phase III for advanced } \\
\text { hepatocellular carcinoma (this is the first } \\
\text { nanoparticle to enter in clinical trials) }\end{array}$ & {$[41,42]$} \\
\hline Dendrimer & $\begin{array}{l}\text { Dendrimers are hyperbranched } \\
\text { nanoparticles composed of a core, } \\
\text { branching units, and functionalized } \\
\text { terminal groups resulting in a nearly } \\
\text { perfect three-dimensional geometric pattern. } \\
\text { These can be synthesized via two major approaches: } \\
\text { (a) divergent approaches and (b) convergent approaches. }\end{array}$ & $\begin{array}{l}\text { - DEP }{ }^{\text {TM }} \text { docetaxel-Dendrimer-enhanced } \\
\text { docetaxel (Taxotere } \AA \text { ), of Starpharma, } \\
\text { is under phase I clinical trials for the } \\
\text { treatment of a wide range of solid tumors } \\
\text { including breast, lung, and prostate. }\end{array}$ & [43] \\
\hline Polymeric micelle & $\begin{array}{l}\text { Formed from the self-assembly of amphiphilic-block } \\
\text { co-polymers. These are composed of a hydrophobic } \\
\text { core and a hydrophilic corona. }\end{array}$ & $\begin{array}{l}\text { - Genexol-PM is currently under investigation } \\
\text { for the treatment of breast, lung, } \\
\text { and pancreatic cancers. }\end{array}$ & [44] \\
\hline Nanocrystals & $\begin{array}{l}\text { Nanocrystals are carrier-free solid drug particles. } \\
\text { These are synthesized by high-pressure } \\
\text { homogenization or wet milling } \\
\text { (the colloidal dispersions of drug crystals, } \\
\text { stabilized by surfactants or polymers). }\end{array}$ & $\begin{array}{l}\text { - Pexceed® (paclitaxel-containing nanocrystal } \\
\text { product of Angiotech Pharmaceuticals) } \\
\text { is currently under phase II investigation. } \\
\text { - Theralux (thymectacin-containing } \\
\text { nanocrystal product of Celmed BioScience) } \\
\text { is currently under phase II investigation. }\end{array}$ & {$[45]$} \\
\hline
\end{tabular}

arginine-glycine-aspartic acid (RGD) peptide for specific delivery of anti-miRNA antisense oligonucleotides to target av $\beta 3$ integrin present on the tumor neovasculature. AntimiR-296 antisense oligonucleotides delivered by nanoparticles decreased microvessel formation within Matrigel by suppressing the invasion of cluster of differentiation 31 (CD31)positive cells and prompting hepatocyte growth factorregulated tyrosine kinase substrate expression in angiogenic endothelial cells [79].

miRNA gold nanoparticle conjugates have been shown to control cellular processes by supplementing the endogenous miRNA levels in human prostate cancer cells. The miRNAgold nanoparticles mimicked human miR-205 and decreased the expression of protein kinase $\mathrm{C}$ epsilon (PRKCE) by $52 \%$ compared to cells treated with control particles functionalized with non-targeting sequences [80]. Valadi et al. reported miRNA delivery from exosomes to human and mouse mast cells. The in vitro translation study proved the functioning of exosome mRNAs. They reported that the RNA from mast cell exosomes is transferable to other mouse and human mast cells [81].

Saraiva et al. developed nanoparticles to deliver miR-124 into neural stem/progenitor cells and boost neuronal differentiation and maturation in vitro. The intracerebroventricular injection of miR-124 nanoparticles increased the number of new neurons in the olfactory bulb of healthy and 6hydroxidopamine-lesioned mice, a model for Parkinson's disease. Importantly, miR-124 nanoparticles enhanced the migration of new neurons into the 6-hydroxidopamine-lesioned striatum, culminating in motor function improvement [82].

Cai et al. developed monomethoxy(polyethylene glycol)poly(D,L-lactide-co-glycolide)-poly(L-lysine)-lactobionic acid-antivascular endothelial growth factor antibody (mPEGPLGA-PLL-LA/VEGFab or PEAL-LA/VEGFab) 
Fig. 3 Schematic representation of a multifunctional nanocarrier

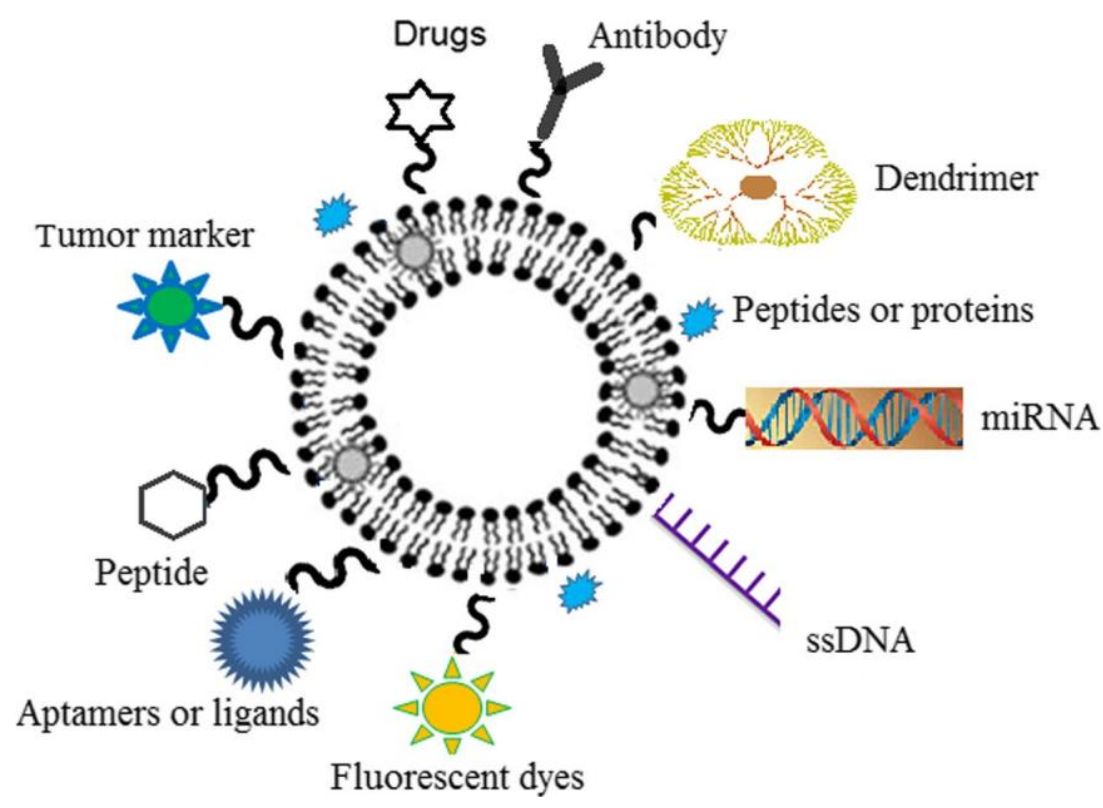

nanoparticles to restore the expression of miR-99a both in vitro and in vivo, to inhibit hepatic carcinoma progression. The nanoparticles selectively and effectively delivered miR99a to hepatic carcinoma cells based on the double-targeting character of these nanoparticles, thereby offering potential for translation into effective clinical therapies for hepatic carcinoma [83]. Mandli et al. reported novel electrochemical biosensor gold nanoparticles for miRNA-21 determination. The developed biosensor exhibited selective and sensitive detection with a linear range from $200 \mathrm{pM}$ to $388 \mathrm{nM}$, and the detection limit was 100 pM [84].

miRNA-145-based magnetic nanoparticles have shown promising anticancer efficacy in pancreatic cancer cell. The miR-NA145 re-expression resulted in the downregulation of mucin MUC13, pAKT, and HER2 and inhibition of cell proliferation, migration, clonogenicity, and invasion of cancer cells [85]. Nanoparticles prepared using biodegradable polycationic prodrug synthesized from a polyamine analog N1,N11-bisethylnorspermine have shown promising results in simultaneous regulation of polyamine metabolism and miRNA delivery for combination cancer therapy [86]. Chen et al. developed liposome-polycation-hyaluronic acid nanoparticles modified with a tumor-targeting single-chain antibody fragment for systemic co-delivery of miRNA and siRNA into experimental lung metastasis of murine B16F10 melanoma. These nanoparticles significantly reduced tumor load and downregulated the survivin expression in the metastatic tumor [74]. Babar and coworkers fabricated surfacemodified anti-miRNA-loaded PLGA nanoparticles using double-emulsion solvent evaporation technique. The study claimed systemic delivery of antisense peptide nucleic acid which inhibited miRNA-155 and suggested promising therapeutic benefits for lymphoma [87]. All the above-stated attempts clearly emphasize and highlight the application and benefits of nanotechnology as a carrier for miRNAs in the cancer treatment. Table 3 summarizes current commercial investments in miRNA therapeutics.

\section{Role of nanoparticles in biosenseor technology}

Various electrochemical nanobiosensors have been fabricated for detection or quantification of valuable miRNAs. The First electrochemical miRNA biosensor was described in 2006 [94]. Azimzadeh et al. reviewed the role of nanotechnology in nanobiosensor development for application in microRNA detection [31]. Biomarkers are divided into two categories based on their application, viz, diagnostic biomarkers and screening biomarkers. MicroRNAs are one of the most reliable biomarkers reported for the early detection, diagnosis, metastasis, prognosis, and assessment of treatment [95, 96]. Northern blotting, microarray, and polymerase chain reaction are the most common methods used for the detection of miRNAs [97].

Wang et al. reported that alpha-hemolysin protein-based nanopore miRNA sensors detected miRNAs at the single molecular level in plasma samples from lung cancer patients without amplification of the microRNA [98]. In a recent report, Wei et al. developed a magnetic fluorescent miRNAsensing system for the rapid and sensitive detection of miRNAs from cell lysates and serum samples [99]. Albumin nanoparticles were prepared from inherently biocompatible bovine serum albumin. The results suggested a broad linear detection range of $10 \mathrm{fM}-10 \mathrm{nM}$ and a low detection limit of $9 \mathrm{fM}$ within $100 \mathrm{~min}$ by detecting a model target miRNA-21. Based on gold nanoparticle-decorated molybdenum sulfide $\left(\mathrm{MoS}_{2}\right)$ nanosheet, a dual-mode electronic biosensor was 
Drug Deliv. and Transl. Res.

Table 2 Nanotechnology-based drug products for cancer therapy under different stages of clinical investigations

\begin{tabular}{|c|c|c|c|c|}
\hline Drug product & Active ingredient & Indications & Stage & Ref. \\
\hline Aroplatin & Cisplatin analog & Colorectal cancer & $\begin{array}{l}\text { Phase } \\
\text { II }\end{array}$ & [50] \\
\hline Atragen & Transretinoic acid & Acute promyelocytic leukemia & $\begin{array}{l}\text { Phase } \\
\text { II }\end{array}$ & [51] \\
\hline $\begin{array}{l}\text { Aurimmune } \\
\quad \text { (CYT-6091) }\end{array}$ & $\begin{array}{l}\text { Recombinant human tumor necrosis } \\
\text { factor alpha (TNF- } \alpha)\end{array}$ & Head and neck cancers & $\begin{array}{c}\text { Phase } \\
\text { II }\end{array}$ & {$[52]$} \\
\hline Auroshell & Gold-silica nanoshells & Aurolace therapy of cancer & $\begin{array}{l}\text { Phase } \\
\text { I }\end{array}$ & {$[52]$} \\
\hline BIND-014 & Docetaxel & $\begin{array}{l}\text { Breast cancer, metastatic castrate-resistant } \\
\text { prostate cancer, head and neck cancers, and gastric cancer }\end{array}$ & $\begin{array}{c}\text { Phase } \\
\text { II }\end{array}$ & [53] \\
\hline C-VISA BikDD & Pro-apoptotic Bik gene & Pancreatic cancer & $\begin{array}{l}\text { Phase } \\
\text { I }\end{array}$ & [54] \\
\hline $\mathrm{CPX}-1$ & Floxuridine & Colorectal cancer & $\begin{array}{c}\text { Phase } \\
\text { II }\end{array}$ & {$[55$, } \\
\hline \multicolumn{5}{|l|}{$56]$} \\
\hline CRLX101 & Camptothecin & Cancer treatment & $\begin{array}{c}\text { Phase } \\
\text { II }\end{array}$ & {$[53$,} \\
\hline \multicolumn{5}{|l|}{$55]$} \\
\hline CT-2103 & $\begin{array}{l}\text { Poly-(L)-Glutamic } \\
\text { acid-paclitaxel/camptothecin }\end{array}$ & Ovarian cancer & $\begin{array}{c}\text { Phase } \\
\text { III }\end{array}$ & [57] \\
\hline Clariscan & Enhanced MRI constrast & Solid tumor & $\begin{array}{c}\text { Phase } \\
\text { III }\end{array}$ & [58] \\
\hline EndoTAG-I & Paclitaxel & Breast cancer/pancreatic cancer & $\begin{array}{c}\text { Phase } \\
\text { II }\end{array}$ & [59] \\
\hline L-Annamycin & Annamycin & Acute lymphocytic leukemia & $\begin{array}{l}\text { Phase } \\
\text { II }\end{array}$ & [56] \\
\hline LEP-ETU & Paclitaxel & Ovarian/breast/lung cancers & $\begin{array}{c}\text { Phase } \\
\text { II }\end{array}$ & [57] \\
\hline Lipoplatin & Cisplatin & Pacreatic/head/neck/ and breast cancers & $\begin{array}{c}\text { Phase } \\
\text { III }\end{array}$ & [58] \\
\hline MCC-465 & Doxorubicin & Anticancer & $\begin{array}{l}\text { Phase } \\
\text { I }\end{array}$ & [60] \\
\hline MBP-426 & Oxaliplatin & Anticancer & $\begin{array}{l}\text { Phase } \\
\text { II }\end{array}$ & {$[61$,} \\
\hline \multicolumn{5}{|l|}{ 62] } \\
\hline MTX-HSA & Methotrexate & Kidney cancer & $\begin{array}{c}\text { Phase } \\
\text { II }\end{array}$ & [63] \\
\hline NK105 & Paclitaxel & Gastric cancer & $\begin{array}{l}\text { Phase } \\
\text { II }\end{array}$ & {$[56$, } \\
\hline \multicolumn{5}{|l|}{ 64] } \\
\hline NKTR-105 & PEG-docetaxel & Solid tumors & $\begin{array}{l}\text { Phase } \\
\text { I }\end{array}$ & [65] \\
\hline NK911 & Doxorubicin & Solid tumors & $\begin{array}{c}\text { Phase } \\
\text { III }\end{array}$ & [57] \\
\hline $\begin{array}{l}\text { Opaxio }^{\mathrm{TM}} \text { or } \\
\text { CT-2103 }\end{array}$ & Paclitaxel poliglumex & Ovarian cancer & $\begin{array}{c}\text { Phase } \\
\text { III }\end{array}$ & [66] \\
\hline OSI-211 & Lurtotecan & Lung cancer/recurrent ovarian & $\begin{array}{l}\text { Phase } \\
\text { II }\end{array}$ & [57] \\
\hline Panzem NCD & Panzem & Several types of cancers & $\begin{array}{c}\text { Phase } \\
\text { II }\end{array}$ & [67] \\
\hline ProLindac $^{\mathrm{TM}}$ & Oxaliplatin & Ovarian cancer & $\begin{array}{l}\text { Phase } \\
\text { II }\end{array}$ & {$[67$,} \\
\hline \multicolumn{5}{|l|}{ 68] } \\
\hline Paclical & Paclitaxel & Ovarian cancer & $\begin{array}{c}\text { Phase } \\
\text { III }\end{array}$ & [66] \\
\hline SPI-77 & Cisplatin & Head/neck cancers/lung cancer & $\begin{array}{c}\text { Phase } \\
\text { III }\end{array}$ & [56] \\
\hline ThermoDox $^{\mathrm{TM}}$ & Doxorubicin & Liver cancer, breast cancer & $\begin{array}{c}\text { Phase } \\
\text { III }\end{array}$ & [66] \\
\hline
\end{tabular}


Table 3 Companies investing in the development of miRNA therapeutics

\begin{tabular}{|c|c|c|c|c|}
\hline Company & Product & Chemical composition and properties & Diseases/product category & Ref. \\
\hline $\begin{array}{l}\text { Regulus } \\
\text { Therapeutics }\end{array}$ & RG101 & $\begin{array}{l}\text { miRNA inhibitors using 2'-methoxyethyl, } \\
\text { 2'-fluoro RNA, bicyclic ribose modifications }\end{array}$ & $\begin{array}{l}\text { Immuno-inflammatory, } \\
\text { cardiovascular, metabolic } \\
\text { diseases; oncology; fibrosis; and hepatitis } \\
\text { C infection }\end{array}$ & {$[88,89]$} \\
\hline $\begin{array}{l}\text { miRagen } \\
\text { Therapeutics }\end{array}$ & MRG-201 & A synthetic microRNA mimic (promiR) to microRNA-29b & Antifibrosis & {$[90]$} \\
\hline $\begin{array}{l}\text { miRagen } \\
\text { Therapeutics }\end{array}$ & MRG-106 & $\begin{array}{l}\text { A synthetic microRNA antagonist } \\
\text { (LNA antimiR®) of microRNA-155 }\end{array}$ & Anticancer & {$[90]$} \\
\hline $\begin{array}{l}\text { Santaris } \\
\text { Pharma A/S }\end{array}$ & Miravirsen & miR-122 inhibitors using locked nucleic acid chemistry & $\begin{array}{l}\text { Cancer and inflammatory diseases, } \\
\text { hepatitis } \mathrm{C} \text { infection }\end{array}$ & {$[91,92]$} \\
\hline $\begin{array}{l}\text { Mirna } \\
\text { Therapeutics }\end{array}$ & MRX34 & $\begin{array}{l}\text { miRNA replacement using small interfering RNA } \\
\text { (siRNA); deliver high numbers of microRNA } \\
\text { mimic molecules to cancerous cells }\end{array}$ & Non-small-cell lung cancer and prostate cancer & [93] \\
\hline
\end{tabular}

developed for miRNA-21 detection. The proposed biosensor displayed high selectivity and stability to determine miRNA21 in human serum samples with satisfactory results [100].

The development of microRNA biosensors has attracted great attention. miRNA is considered as an ideal biomarker for cancer detection in early stages. Electrochemical biosensors have been used widely due to the fact that they can provide simple, rapid, and reliable detection [101].

\section{miRNAs are important regulators of cancer MDR and metastatic capacity}

Extracellular vesicles serve as important intercellular vectors in the regulation of many biological processes. Microparticles (MPs) are a subtype of extracellular vesicle, typically defined as having a size of $0.1-1 \mu \mathrm{m}$ in diameter, exposure of phosphatidylserine, and the expression of surface antigens originating from their donor cells [68]. MPs also contain functional proteins, second messengers, growth factors, and genetic material from the cell of origin and confer onto recipient cells biological effects [102-111]. MPs together with exosomes are important cancer biomarkers through their discrete protein and nucleic acid signatures [112].

MPs are important mediators in the dissemination of functional multidrug resistance (MDR) in cancer cell populations. Cancer MDR is a significant cause of treatment failure and disease relapse and is attributed to the overexpression of drug efflux transporters belonging to the ATP-binding cassette (ABC) superfamily. MPs can confer MDR through the packaging and intercellular transfer of these functional resistance proteins and nucleic acids from MDR cells to drug-responsive cells [102, 104, 108, 109].

In addition to the presence of proteins and transcripts encoding resistance proteins, these MPs also carry miRNAs, which are involved in the acquisition of MDR and other deleterious traits associated with this complex phenotype. MPs comprise the major source of systemic RNA, including miRNA, the aberrant expression of which appears to be associated with stage, progression, and spread of many cancers [103, 104].

In a study conducted by Bebawy and coworkers in 2012, Affymetrix miRNA microarray was used to explore the miRNA expression profiles of MPs shed from MDR cells as well as cells that acquired MDR following MP transfer [103]. The analysis showed the selective packaging of seven miRNAs including miR-1228*, miR-1246, miR-1308, miR$149 *$, miR-455-3p, miR-638, and miR-923 within the MP cargo upon release from MDR cells. The pathway analysis of the predicted targets for these miRNAs showed target genes to be significantly related to pathways in cancer and at least seven other pathways that were cancer-related. The selective packaging of miRNAs was also reported by the same team for miR-451 and miR-326 in MPs shed from MDR breast and leukemia cells in earlier studies, supporting the presence of a mechanism for the selective dissemination and transfer of miRNAs within cancer cell populations [104]. Following coculture with recipient cells, there was again an increase in the levels of miR-1246, miR-1308, miR-1228*, miR-149*, miR638 , and miR-923 in recipient cells [103]. Certainly, this was attributed to the unloading of MP cargo to the recipient following binding and uptake; however, MP effects on the transcriptional regulation of these miRNAs in recipient cells also cannot be excluded. Indeed, the acquired cell population demonstrated miRNA expression trends reflective of the donor cells, a finding consistent with previous reports demonstrating a Bre-templating $\wedge$ of the transcriptional landscape of recipient cells to reflect that of the donor cells [104].

The abovementioned miRNAs play important roles in cancer cell biology. For instance, the NF-KB inhibitor, NKIRAS1, is targeted by miR-1308. miR-1308 is upregulated in many cancers, including in aggressive inflammatory breast cancer $[113,114]$. Likewise, miR-1228* is highly expressed in malignant mesothelioma [115]. 
The role of miRNAs in the regulation MDR is an emerging area $[103,105,110]$. miR-455-3p, among others selectively packaged in the MP cargo shed from MDR cells, targets the multidrug resistance protein, $P$-glycoprotein $(\mathrm{P}-\mathrm{gp})$, and HIF1AN (hypoxia-inducible factor 1, alpha subunit inhibitor). HIF-1 alpha has been shown to induce MDR in hepatocellular carcinoma [115]. This is consistent with miRNA profiling studies conducted by Bebawy and coworkers [103] which showed resistant leukemia cells to have lower levels of this miRNA compared to drug-sensitive cells, a finding consistent with the resistant state. In the acquired cell population following MP transfer, miR-455-3p levels were suppressed supporting the acquisition of increased P-gp levels.

The role of miRNAs in the regulation of the functional redundancy that resides among members of the ABC transporters, of which the prototypical members include the MDR proteins P-gp $(A B C B 1)$ and multidrug resistance protein $(A B C C 1)$, has also recently been demonstrated [116]. This significant functional redundancy that exists between members of this superfamily of drug transporters is attributed to significant sequence homology, broad and overlapping substrate specificities, and significant tissue co-localization. This ensures a fail-proof survival mechanism for cell survival, more so in the context of malignancy. This was first attributed to the suppression of endogenous $A B C C 1$ transcript levels in recipient CEM cells by MPs shed from $A B C B 1$-overexpressing $\mathrm{VLB}_{100}$ cells to the presence of miRNA326 in the MP cargo and to its subsequent transfer to recipient cells [104]. Indeed, the suppressive effect of miR-326 on $A B C C 1$ has been shown previously and MRP1 expression is inversely correlated with miR-326 in advanced breast cancer [117].

The transfer of miR-326 from P-gp-mediated MDR breast cancer and leukemia cells to recipient cells was previously shown [104]. Relative to breast cancer MPs, leukemic MPs were shown to package significantly greater amounts of the $A B C B 1$ transcripts. Despite the miR-326 levels in both breast cancer and leukemia MPs being comparable, suppression of $A B C C 1$ was only observed in recipient cells following coculture with the latter [104]. The molecular basis for the differential effect of miR326 on $A B C C 1$ suppression in breast cancer and leukemia cells has been shown to be regulated by the presence of $A B C B 1$ transcript demonstrating a novel mechanism regulating the expression of $\mathrm{ABC}$ transporters in cancer. This work positions $A B C B 1$ mRNA as a transcriptional regulator of $A B C C 1$ through its actions on miRNA326 of which there are no known putative binding sites [110].

Other miRNAs associated with cancer MDR include miR27a and miR-451. These miRNAs have been detected in resistant breast cancer and leukemia cells as well as in their MP cargo [101] with the former possibly playing a role in the upregulation of $A B C B 1$ transcript in recipient breast cancer cells. miR-345 and miR-7 have also been previously shown to target $A B C C l$ in MDR breast cancer cells relative to parental cells [118].
Although the development of MDR and metastases are both major considerations in the clinical treatment of cancer, their significance in the context of one another has only recently been studied. Microparticles shed from MDR breast cancer cells also mediate the intercellular transfer ofmiRNA-503 to alter the migration and invasion capacities of recipient breast cancer cell populations [107]. Microarray analysis identified miRNAs common to the resistant state and which contribute to the dissemination of metastatic traits. Among the miRNAs identified, miR503 was downregulated in recipient cells following coculture with MPs isolated from drug-resistant cells. miR503 was shown to be inversely associated with metastatic and invasive capacities, as demonstrated using wound healing/scratch migration assays and Matrigel@-coated transwell invasion assays. This is consistent with earlier reports whereby miR-503 was previously shown to be involved in the development of drug resistance and metastatic traits, with reduced levels of miR-503 being identified in drug-resistant cells and highly metastatic cells $[119,120]$. Activation of the NF-KB pathway has been shown to suppress the expression of miR-503 in epithelial cells and may also be responsible for the miRNA-503 suppression following MP transfer [121]. Reduced levels of miR-503 have been observed in cisplatin-resistant non-small-cell lung cancer cells (NSCLC), while its overexpression resensitizes cells to cisplatin via modulation of the apoptosis regulator Bcl-2. miR-503 has also been shown to directly target and repress the Fanconi anemia complementation group A protein (FANCA) gene to sensitize NSCLC to cisplatin treatment [122].

miR-503 is also an important tumor suppressor, the overexpression of which inhibits the migration and invasion of highly invasive hepatocellular carcinoma cells. miR-503 also acts to induce $\mathrm{G} 1$ cell cycle arrest and reduce cell proliferation [119, 123, 124]. Its tumor-suppressive activity has been shown to be via regulation of PI3K/AKT signaling by its effect on inhibiting AKT activation [120, 125].

miRNA-494 is another miRNA found in abundance in recipient cells following co-culture with MPs isolated from MDR cells [107]. miR-494 is predicted to target the focal adhesion kinase family-interacting protein of $200-\mathrm{kDa}$ (FIP200) gene. FIP200 binds directly to the kinase domain of proline-rich tyrosine kinase 2 (PYK-2) to inhibit its activity [126]. miR-494 downregulation of the FIP200 gene may be responsible for enhanced PYK2-dependent phosphorylation of AKT and activation of PI3K/AKT pathway resulting in increased metastatic capacity in recipient cells following MP co-culture [107]. MPs shed from resistant cells not only mediate the intercellular transfer of MDR but are also implicated in promoting migration and invasion in recipient cells, potentially providing a link between these two deleterious traits. 


\section{Conclusions and future prospects}

miRNA therapeutics provide a promising strategy for the treatment of disease. The present miRNA research is mainly centered on post-transcriptional gene silencing induced by RISC binding to the $3^{\prime}$-untranslated region of the mRNA [127]. Extensive research is required to develop rapid and sensitive analytical methods for the identification of miRNAs present in a particular cell, tissue, or fluids (such as serum and plasma) [28]. Gene silencing with miRNAs using nanoparticles is another area of investigation [128]. During the past decade, a strong research focus has been on the biology of miRNAs with special attention to miRNA regulation and miRNAs as biological targets in human disease.

The first miRNA-targeted drug, LNA-antimir-122, is under phase II clinical trial (Miravirsen, Santaris Pharma). Over the last several years, extensive efforts have been given for the development of liposome- and nanoparticleassociated and naked oligonucleotides for targeted delivery of miRNA [127]. Various therapeutic miRNAs have been studied in the context of exosome delivery vehicles [129]. Unfortunately, only a few miRNA therapeutics have reached clinical trials (Table 1).

An ideal carrier system should protect the therapeutic agent from the circulatory nucleases and deliver it intact to the target site. Despite the advancement in miRNAbased therapies to clinical trials, there remain many hurdles which need to be overcome for the use of the novel nanocarrier-based delivery technologies. Irrespective of their clinical significances, nanocarriers are also not devoid of limitations. These delivery vehicles are reported for intravenous or subcutaneous administration. The development of oral delivery vehicles is needed in advancing miRNA delivery through clinical development and commercial application [130].

A successful nanocarrier-based miRNA therapeutic must be safe and composed of biocompatible active/ effector ingredients together with an organic or inorganic core; it must have a sustainable half-life (PEGylation is the most used method to achieving this) and should have target specificity and outstanding pharmacokinetic profile; the manufacturing process must be robust and feasible. The product needs FDA approval [32, 131-134]. There is significant risk for investment in miRNA therapeutics due to the biological challenges, the cost of production and scale-up, and clinical approval challenges [133].

Overall, the application of nanotechnology is paving a new path in the development of effective drug delivery systems containing miRNAs. This will introduce new vistas in clinically considering their various merits like maximum efficacy, targeted effects, and improved patient compliance.
Compliance with ethical standards

Conflict of interest The authors declare that they have no conflict of interest.

\section{References}

1. Lee RC, Feinbaum RL, Ambros V. The C. elegans heterochronic gene LIN-4 encodes small RNAs with antisense complementarity to LIN-14. Cell. 1993;75:843-54.

2. Giza DE, Vasilescu C, Calin GA. Key principles of miRNA involvement in human diseases. Discoveries (Craiova). 2014;2(4): e34. 10.15190/d.2014.26.

3. Ha TY. MicroRNAs in human diseases: from cancer to cardiovascular disease. Immune Netw. 2011;11(3):135-54.

4. Huiyuan W, Yifan J, Huige P, Yingzhi C, Peizhi Z, Yongzhuo H. Recent progress in microRNA delivery for cancer therapy by nonviral synthetic vectors. Adv Drug Deliv Rev. 2015;81:142-60.

5. Dua K, Hansbro NG, Foster PS, Hansbro PM. MicroRNAs as therapeutics for future drug delivery systems in treatment of lung diseases. Drug Deliv and Transl Res. 2017;7(1):168-78.

6. Roy S, Sen CK. miRNA in wound inflammation and angiogenesis. Microcirculation. 2012;19(3):224-32.

7. Montgomery RL, Hullinger TG, Semus HM, Dickinson BA, Seto AG, Lynch JM, et al. Therapeutic inhibition of miR-208a improves cardiac function and survival during heart failure. Circulation. 2011;124(14):1537-47.

8. Wong L, Wang J, Liew OW, Richards AM, Chen YT. MicroRNA and heart failure. Int J Mol Sci. 2016;17:502. https://doi.org/10. 3390/ijms17040502.

9. Ji LY, Jiang DQ, Dong NN. The role of miR-145 in microvasculature. Pharmazie. 2013;68(6):387-91.

10. Alizadeh S, Azizi SG, Soleimani M, Farshi Y, Khatib ZK. The role of microRNAs in myeloproliferative neoplasia. Int J Hematol Oncol Stem Cell Res. 2016;10(3):172-85.

11. Deng Z, He Y, Yang X, Shi H, Shi A, Lu L, He L. MicroRNA-29: a crucial player in fibrotic disease. Mol Diagn Ther. 2017;21(3): 285-294.

12. Stahlhut C, Slack FJ. Combinatorial action of microRNAs let-7 and miR-34 effectively synergizes with erlotinib to suppress nonsmall cell lung cancer cell proliferation. Cell Cycle. 2015;14(13): 2171-80.

13. Degliangeli F, Pompa PP, Fiammengo R. Nanotechnology-based strategies for the detection and quantification of microRNA. Chem Eur J. 2014;20:9476-92.

14. Kong W, Zhao JJ, He L, Cheng QJ. Strategies for profiling microRNA expression. J Cell Physiol. 2009;218:22-5.

15. He L, Hannon GJ. MicroRNAs: small RNAs with a big role in gene regulation. Nat Rev. 2004;5:522-31.

16. Davis BN, Hata A. Regulation of microRNA biogenesis: a miRiad of mechanisms. Cell Commun Signal. 2009;7:18. https://doi.org/ 10.1186/1478-811X-7-18.

17. The miRBase Sequence Database - Release 21 June 2014. http:// www.mirbase.org/index.shtml. Accessed 14 April 2017.

18. Hebert SS, Horre K, Nicolai L, Papadopoulou AS, Mandemakers W, Silahtaroglu AN, et al. Loss of microRNA cluster miR-29a/b-1 in sporadic Alzheimer's disease correlates with increased BACE1/ $\beta$-secretase expression. Proc Natl Acad Sci U S A. 2008;105: 6415-20.

19. Caporali A, Emanueli C. MicroRNA regulation in angiogenesis. Vasc Pharmacol. 2011;55:79-86.

20. Corsten MF, Miranda R, Kasmieh R, Krichevsky AM, Weissleder R, Shah K. MicroRNA-21 knockdown disrupts glioma growth 
in vivo and displays synergistic cytotoxicity with neural precursor cell-delivered S-TRAIL in human gliomas. Cancer Res. 2007;67(19):8994-9000.

21. Hsu AC, Dua K, Starkey MR, Haw TJ, Nair PM, Nichol K, et al. MicroRNA-125a and -b inhibit A20 and MAVS to promote inflammation and impair antiviral response in COPD. JCI Insight. 2017;2(7):e90443. https://doi.org/10.1172/jci.insight.90443.

22. Hu Y, Ehli EA, Boomsma DI. MicroRNAs as biomarkers for psychiatric disorders with a focus on autism spectrum disorder: current progress in genetic association studies, expression profiling, and translational research. Autism Res 2017;10(7):11841203.

23. Calin GA, Ferracin M, Cimmino A, Di Leva G, Shimizu M, Wojcik SE, et al. A microRNA signature associated with prognosis and progression in chronic lymphocytic leukemia. N Engl J Med. 2005;353(17):1793-801.

24. Zhao J, Xu T, Wang F, Cai W, Chen L. miR-493-5p suppresses hepatocellular carcinoma cell proliferation through targeting GP73. Biomed Pharmacother. 2017;90:744-51.

25. Sun D, Wang C, Long S, Ma Y, Guo Y, Huang Z, et al. EBP-bactivated microRNA-223 promotes tumour growth through targeting RASA1 in human colorectal cancer. Br J Cancer. 2015;112:1491-500

26. Valencia-Sanchez MA, Liu J, Hannon GJ, Parker R. Control of translation and mRNA degradation by miRNAs and siRNAs. Genes Dev. 2006;20:515-24.

27. MacFarlane LA, Murphy PR. MicroRNA: biogenesis, function and role in cancer. Curr Genomics. 2010;11(7):537-61.

28. Catuogno S, Esposito CL, Quintavalle C, Cerchia L, Condorelli G, De Franciscis V. Recent advance in biosensors for micrornas detection in cancer. Cancers. 2011;3:1877-98.

29. Conde J, Edelman ER, Artzi N. Target-responsive DNA/RNA nanomaterials for microRNA sensing and inhibition: the jack-ofall-trades in cancer nanotheranostics? Adv Drug Deliv Rev. 2015;81:169-83.

30. Broderick JA, Zamore PD. MicroRNA therapeutics. Gene Ther. 2011;18:1104-10.

31. Azimzadeh M, Rahaie M, Nasirizadeh N, Daneshpour M, NaderiManesh H. Electrochemical miRNA biosensors: the benefits of nanotechnology. Nanomed Res J. 2017;2(1):36-48.

32. Pasquinelli AE. MicroRNAs and their targets: recognition, regulation and an emerging reciprocal relationship. Nat Rev Genet. 2012;13(4):271-82.

33. Li M, Li J, Ding X, He M, Cheng SY. MicroRNA and cancer. AAPS J. 2010;12(3):309-17.

34. Zhou J, Shum KT, Burnett JC, Rossi JJ. Nanoparticle-based delivery of RNAi therapeutics: progress and challenges. Pharmaceuticals. 2013;6:85-107.

35. Jatzkewitz H. Incorporation of physiologically-active substances into a colloidal blood plasma substitute. I Inc Mescaline Peptide Polyvinylpyrrolidone Hoppe-Seyler's Zeitschrift fur Physiol Chemie. 1954;297:149.

36. Bangham A, Horne R. Negative staining of phospholipids and their structural modification by surface-active agents as observed in the electron microscope. J Mol Biol. 1964;8:660-IN10.

37. Bangham A, Standish M, Watkins J. Diffusion of univalent ions across the lamellae of swollen phospholipids. J Mol Biol. 1965;13: 238-IN27.

38. Scheffel U, Wagner HN, Rhodes BA, Nataraja TK. Albumin microspheres for study of reticuloendothelial system. J Nucl Med. 1972;13:498.

39. Gradishar WJ, Tjulandin S, Davidson N, Shaw H, Desai N, Bhar $\mathrm{P}$, et al. Phase III trial of nanoparticle albumin-bound paclitaxel compared with polyethylated castor oil-based paclitaxel in women with breast cancer. J Clin Oncol. 2005;23:7794-803.
40. Hare JI, Lammers T, Ashford MB, Puri S, Storm G, Barry ST Challenges and strategies in anti-cancer nanomedicine development: an industry perspective. Adv Drug Deliv Rev. 2017;108: $25-38$.

41. Danhier F. To exploit the tumor microenvironment: since the EPR effect fails in the clinic, what is the future of nanomedicine? J Control Release. 2016;244(Pt A):108-21.

42. Perez-Herrero E, Fernandez-Medarde A. Advanced targeted therapies in cancer: drug nanocarriers, the future of chemotherapy. Eur J Pharm Biopharm. 2015;93:52-79.

43. Leiro V, Garcia JP, Tomas H, Pêgo AP. The present and the future of degradable dendrimers and derivatives in theranostics. Bioconjug Chem. 2015;26(7):1182-97.

44. Aslan B, Ozpolat B, Sood AK, Lopez-Berestein G. Nanotechnology in cancer therapy. J Drug Target. 2013;21(10): 904-13.

45. Lu Y, Chen Y, Gemeinhart RA, Wu W, Li T. Developing nanocrystals for cancer treatment. Nanomedicine (Lond). 2015;10(16):2537-52.

46. Awasthi R, Pant I, Kulkarni GT, Kikuchi IS, Pinto TJA, Dua K, et al. Nano-structure mediated drug delivery: opportunities and challenges. Curr Nanomed. 2016;6(2):78-104.

47. Vasir JK, Reddy MK, Labhasetwar V. Nanosystems in drug targeting: opportunities and challenges. Curr Nanosci. 2005;1: 47-64.

48. Chen J, Hessler JA, Putchakayala K, Panama BK, Khan DP, Hong $\mathrm{S}$, et al. Cationic nanoparticles induce nanoscale disruption in living cell plasma membranes. J Phys Chem B. 2009;113: 11179-85.

49. Champion JA, Katare YK, Mitragotri S. Particle shape: a new design parameter for microand nanoscale drug delivery carriers. J Control Release. 2007;121:3-9.

50. Sen K, Mandal M. Second generation liposomal cancer therapeutics: transition from laboratory to clinic. Int J Pharm. 2013;448: 28-43.

51. Adiseshaiah PP, Hall JB, McNeil SE. Nanomaterial standards for efficacy and toxicity assessment. WIREs. Nanomed Nanobiotechnol.2009;2:99-112.

52. Kumar A, Zhang X, Liang XJ. Gold nanoparticles: emerging paradigm for targeted drug delivery system. Biotechnol Adv. 2013;31:593-606.

53. Sheridan C. Proof of concept for next-generation nanoparticle drugs in humans. Nature Biotechnol. 2012;30(6):471-3.

54. Tiemann K, Rossi JJ. RNAi-based therapeutics-current status, challenges and prospects. EMBO Mol Med. 2009;1:142-51.

55. Svenson S, Wolfgang M, Hwang J, Ryan J, Eliasof S. Preclinical to clinical development of the novel camptothecin nanopharmaceutical CRLX101. J Control Release. 2011;153:49-55.

56. Swami A, Shi J, Gadde S, Votruba A R, Kolishetti N, Farokhzad OC. Nanoparticles for targeted and temporally controlled drug delivery. In: Svenson S, Prud' homme RK, editors. Multifunctional Nanoparticles for Drug Delivery Applications: Imaging, Targeting, and Delivery, Nanostructure Science and Technology. Boston: Springer;2012. pp. 9-29.

57. Soo PL, Dunee M, Liu J, Allen C. Nano sized advanced delivery systems as parenteral formulation strategies for hydrophobic anticancer drugs. In: de Villiers MM, Aramwit P, Kwon GS, editors. Nanotechnology in drug delivery. NY: Springer; 2008. p. 349-84.

58. Bjornerud A, Johansson LO, Ahlstrom HK. Pre-clinical results with Clariscan TM (NC100150 injection); experience from different disease models. MAGMA. 2001;12:99-103.

59. Fasol U, Frost A, Buchert M, Arends J, Fiedler U, Scharr D, et al. Vascular and pharmacokinetic effects of EndoTAG-1 in patients with advanced cancer and liver metastasis. Ann Oncol. 2012;23: 1030-6. 
60. Matsumura Y, Gotoh M, Muro K, Yamada Y, Shirao K, Shimada Y, et al. Phase I and pharmacokinetic study of MCC-465, a doxorubicin (DXR) encapsulated in PEG immunoliposome, in patients with metastatic stomach cancer. Ann Oncol. 2004;15:517-25.

61. Sankhala KK, Mita AC, Adinin R, Wood L, Beeram M, Bullock $\mathrm{S}$, et al. A phase I pharmacokinetic (PK) study of MBP-426, a novel liposome encapsulated oxaliplatin. J Clin Oncol. 2009;27(15S):2535.

62. Safety study of MBP-426 (liposomal oxaliplatin suspension for injection) to treat advanced or metastatic solid tumors. Mebiopharm Co., Ltd 2014. http://clinicaltrials.gov/ct2/show/ NCT00355888. Accessed 8 Feb 2015.

63. Bolling C, Graefe T, Lubbing C, Jankevicius F, Uktveris S, Cesas A, et al. Phase II study of MTX-HSA in combination with Cisplatin as first line treatment in patients with advanced or metastatic transitional cell carcinoma. Investig New Drugs. 2006;24: 521-7.

64. Kato K, Chin K, Yoshikawa T, Yamaguchi K, Tsuji Y, Esaki T, et al. Phase II study of NK105, a paclitaxel-incorporating micellar nanoparticle, for previously treated advanced or recurrent gastric cancer. Investig New Drugs. 2012;30(4):1621-7.

65. Canal F, Sanchis J, Vicent MJ. Polymer-drug conjugates as nanosized medicines. Curr Opin Biotechnol. 2011;22:894-900.

66. Egusquiaguirre SP, Igartua M, Hernandez RM, Pedraz JL. Nanoparticle delivery systems for cancer therapy: advances in clinical and preclinical research. Clin Transl Oncol. 2012;14:8393.

67. Zhang L, FX G, Chan JM, Wang AZ, Langer RS, Farokhzad OC. Nanoparticles in medicine: therapeutic applications and developments. Clin. Pharmacol Therap. 2008;83(5):761-9.

68. Nowotnik DP, Cvitkovic E. ProLindac ${ }^{\text {TM }}$ (AP5346): a review of the development of an HPMA DACH platinum polymer therapeutic. Adv Drug Deliv Rev. 2009;61:1214-9.

69. Gandhi NS, Tekade RK, Chougule MB. Nanocarrier mediated delivery of siRNA/miRNA in combination with chemotherapeutic agents for cancer therapy: current progress and advances. J Control Release. 2014;194:238-56.

70. Yalcin S, Gunduz U. Nanoparticle based delivery of miRNAs to overcome drug resistance in breast cancer. J Nanomed Nanotechnol. 2016;7:414. https://doi.org/10.4172/2157-7439. 1000414.

71. Kato RB, Roy B, De Oliveira FS, Ferraz EP, De Oliveira PT, Kemper AG, et al. Nanotopography directs mesenchymal stem cells to osteoblast lineage through regulation of microRNASMAD-BMP-2 circuit. J Cell Physiol. 2014;229(11):1690-6.

72. De Antonellis P, Liguori L, Falanga A, Carotenuto M, Ferrucci V, Andolfo I, et al. MicroRNA 199b-5p delivery through stable nucleic acid lipid particles (SNALPs) in tumorigenic cell lines. Naunyn Schmiedeberg's Arch Pharmacol. 2013;386(4):287-302.

73. Yoo SS, Razzak R, Bedard E, Guo L, Shaw AR, Moore RB, et al. Layered gadolinium-based nanoparticle as a novel delivery platform for microRNA therapeutics. Nanotechnology. 2014;25: 425102.

74. Chen Y, Zhu X, Zhang X, Liu B, Huang L. Nanoparticles modified with tumor-targeting scFv deliver siRNA and miRNA for cancer therapy. Mol Ther. 2010;18(9):1650-6.

75. Ghosh R, Singh LC, Shohet JM, Gunaratne PH. A gold nanoparticle platform for the delivery of functional microRNAs into cancer cells. Biomaterials. 2013;34:807-16.

76. Tivnan A, Orr WS, Gubala V, Nooney R, Williams DE, McDonagh $\mathrm{C}$, et al. Inhibition of neuroblastoma tumor growth by targeted delivery of micro RNA-34a using antidisialoganglioside GD2 coated nanoparticles. PLoS One. 2012;7(5):e38129. https://doi.org/10.1371/journal.pone. 0038129 .
77. Medina OP, Zhu Y, Kairemo K. Targeted liposomal drug delivery in cancer. Curr Pharm Des. 2004;10:2981-9.

78. Babar IA, Cheng CJ, Booth CJ, Liang X, Weidhaas JB, Saltzman WM, et al. Nanoparticle-based therapy in an in vivo microRNA155 (miR-155)-dependent mouse model of lymphoma. Proc Natl Acad Sci U S A. 2012;109(26):E1695-704. https://doi.org/10. 1073/pnas.1201516109.

79. Liu XQ, Song WJ, Sun TM, Zhang PZ, Wang J. Targeted delivery of antisense inhibitor of miRNA for antiangiogenesis therapy using cRGD-functionalized nanoparticles. Mol Pharm. 2011;8(1):250-9.

80. Hao L, Patel PC, Alhasan AH, Giljohann DA, Mirkin CA. Nucleic acid-gold nanoparticle conjugates as mimics of microRNA. Small. 2011;7(22):3158-62.

81. Valadi H, Ekstrom K, Bossios A, Sjostrand M, Lee JJ, Lotvall JO. Exosome mediated transfer of mRNAs and microRNAs is a novel mechanism of genetic exchange between cells. Nat Cell Biol. 2007;9:654-9.

82. Saraiva C, Ferreira L, Bernardino L. Traceable microRNA-124 loaded nanoparticles as a new promising therapeutic tool for Parkinson's disease. Neurogenesis (Austin). 2016;3(1): e1256855. https://doi.org/10.1080/23262133.2016.1256855.

83. Cai C, Xie Y, Wu L, Chen X, Liu H, Zhou Y, et al. PLGA-based dual targeted nanoparticles enhance miRNA transfection efficiency in hepatic carcinoma. Sci Rep. 2017;7:46250. https://doi.org/ 10.1038/srep46250.

84. Mandli J, Mohammadi H, Amine A. Electrochemical DNA sandwich biosensor based on enzyme amplified microRNA-21 detection and gold nanoparticles. Bioelectrochemistry. 2017;116:17-23.

85. Setua S, Khan S, Yallapu MM, Behrman SW, Sikander M, Khan SS, et al. Restitution of tumor suppressor microRNA-145 using magnetic nanoformulation for pancreatic cancer therapy. J Gastrointest Surg. 2017;21(1):94-105.

86. Xie Y, Murray-Stewart T, Wang Y, Yu F, Li J, Marton LJ, et al. Self-immolative nanoparticles for simultaneous delivery of microRNA and targeting of polyamine metabolism in combination cancer therapy. J Control Release. 2017;246:110-9.

87. Babar IA, Cheng CJ, Booth CJ, Liang X, Weidhaas JB, Saltzman WM, et al. Nanoparticle-based therapy in an in vivo microRNA155 (miR-155)-dependent mouse model of lymphoma. Proc Natl Acad Sci U S A. 2012;109(26):E1695-704.

88. Esau C, Davis S, Murray SF, Yu XX, Pandey SK, Pear M, et al. miR-122 regulation of lipid metabolism revealed by in vivo antisense targeting. Cell Metab. 2006;3:87-98.

89. Krutzfeldt J, Kuwajima S, Braich R, Rajeev KG, Pena J, Tuschl T, et al. Specificity, duplex degradation and subcellular localization of antagomirs. Nucleic Acids Res. 2007;35:2885-92.

90. van der Ree MH, de Vree JM, Stelma F1, Willemse S, van der Valk M, Rietdijk S, et al. Safety, tolerability, and antiviral effect of RG101 in patients with chronic hepatitis C: a phase 1B, double-blind, randomised controlled trial. Lancet. 2017;389(10070):709-717.

91. Orom Kauppinen S, Lund AH. LNA-modified oligonucleotides mediate specific inhibition of microRNA function. Gene. 2006;372:137-41.

92. Elmen J, Lindow M, Schutz S, Lawrence M, Petri A, Obad S, et al. LNA-mediated microRNA silencing in non-human primates. Nature. 2008;452:896-9.

93. Hydbring P, Badalian-Very G. Clinical applications of microRNAs. Version 2. F1000Res. 2013;2:136. https://doi.org/ 10.12688/f1000research.2-136.v2.

94. Xia N, Zhang L. Nanomaterials-based sensing strategies for electrochemical detection of microRNAs. Materials. 2014;7:5366-84.

95. Wu L, Qu X. Electrochemical DNA biomarker detection: recent achievements and challenges. Chem Soc Rev. 2015;44(10):296397. 
96. Li J, Tan S, Kooger R, Zhang C, Zhang Y. MicroRNAs as novel biological targets for detection and regulation. Chem Soc Rev. 2014;43(2):506-17.

97. Vigneshvar S, Sudhakumari CC, Senthilkumaran B, Prakash H. Recent advances in biosensor technology for potential applications-an overview. Frontiers in Bioengineering and Biotechnology. 2016;4:Article 11. https://doi.org/10.3389/fbioe.2016.00011.

98. Wang Y, Zheng D, Tan Q, Wang M, Gu LQ. Nanopore-based detection of circulating microRNAs in lung cancer patients. Nat Nanotechnol. 2011;6(10):668-74.

99. Wei T, Du D, Wang Z, Zhang W, Lin Y, Dai Z. Rapid and sensitive detection of microRNA via the capture of fluorescent dyes-loaded albumin nanoparticles around functionalized magnetic beads. Biosens Bioelectron. 2017;94:56-62.

100. Su S, Cao W, Liu W, Lu Z, Zhu D, Chao J, et al. Dual-mode electrochemical analysis of microRNA-21 using gold nanoparticle-decorated $\mathrm{MoS}_{2}$ nanosheet. Biosens Bioelectron. 2017;94:552-9.

101. Keshavarz M, Behpour M, Rafiee-pour MA. Recent trends in electrochemical microRNA biosensors for early detection of cancer. RSC Adv. 2015;5:35651-60.

102. Bebawy M, Combes V, Lee E, Jaiswal R, Gong J, Bonhoure A, et al. Membrane microparticles mediate transfer of P-glycoprotein to drug sensitive cancer cells. Leukemia. 2009;23(9):1643-9.

103. Jaiswal R, Luk F, Gong J, Mathys JM, Emile G, Grau R, et al. Microparticle conferred microRNA profiles-implications in the transfer and dominance of cancer traits. Mol Cancer. 2012a;11:37. https://doi.org/10.1186/1476-4598-11-37.

104. Jaiswal R, Gong J, Sambasivam S, Combes V, Mathys JM, Davey $\mathrm{R}$, et al. Microparticle-associated nucleic acids mediate trait dominance in cancer. FASEB J. 2012b;26(1):420-9.

105. JF L, Luk F, Gong J, Jaiswal R, Grau GE, Bebawy M. Microparticles mediate MRP1 intercellular transfer and the retemplating of intrinsic resistance pathways. Pharmacol Res. 2013;76:77-83.

106. Pokharel D, Padula MP, JF L, Tacchi JL, Luk F, Djordjevic SP, et al. Proteome analysis of multidrug-resistant, breast cancerderived microparticles. J Extracell Vesicles. 2014;3:24384. https://doi.org/10.3402/jev.v3.24384.

107. Gong J, Luk F, Jaiswal R, Bebawy M. Microparticles mediate the intercellular regulation of microRNA-503 and proline-rich tyrosine kinase 2 to alter the migration and invasion capacity of breast cancer cells. Front Oncol. 2014;4(220):1-11. https://doi.org/10. 3389/fonc.2014.00220.

108. Pokharel D, Wijesinghe P, Oenarto V, JF L, Sampson DD, Kennedy BF, et al. Deciphering cell-to-cell communication in acquisition of cancer traits: extracellular membrane vesicles are regulators of tissue biomechanics. OMICS: A Journal of Integr Biol.2016;20(8):462-9.

109. Lu JF, Pokharel D, Padula MP, Bebawy M. A novel method to detect translation of membrane proteins following microvesicle intercellular transfer of nucleic acids. J Biochem. 2016;160(5): 281-9.

110. JF L, Pokharel D, Bebawy M. A novel mechanism governing the transcriptional regulation of $\mathrm{ABC}$ transporters in MDR cancer cells. Drug Deliv Transl Res. 2017;7(2):276-85.

111. Jaiswal R, Johnson MS, Pokharel D, Krishnan SR, Bebawy M. Microparticles shed from multidrug resistant breast cancer cells provide a parallel survival pathway through immune evasion. BMC Cancer. 2017;17:104. https://doi.org/10.1186/s12885-0173102-2.

112. Krishnan SR, Luk F, Brown RD, Suen H, Kwan Y, Bebawy M. Isolation of human CD138(+) microparticles from the plasma of patients with multiple myeloma. Neoplasia. 2016;18(1):25-32.

113. Wu Q, Lu Z, Li H, Lu J, Guo L, Ge Q. Next-generation sequencing of microRNAs for breast cancer detection. J Biomed Biotechnol. 2011;2011:597145. https://doi.org/10.1155/2011/597145.
114. Lerebours GC F, Tozlu-Kara S, Vacher S, Lidereau R, Bieche I. MicroRNA expression profiling of inflammatory breast cancer. In Thirty-second annual CTRC-AACR San Antonio breast cancer symposium. San Antonio, TX: Cancer Research 2009: Abstract nr 6118; 2009. December 15, 2009.

115. Guled M, Lahti L, Lindholm PM, Salmenkivi K, Bagwan I, Nicholson AG, et al. CDKN2A, NF2, and JUN are dysregulated among other genes by miRNAs in malignant mesothelioma-a miRNA microarray analysis. Genes Chromosom Cancer. 2009;48(7):615-23.

116. Zhu H, Chen XP, Luo SF, Guan J, Zhang WG, Zhang BX. Involment of hypoxia-inducible factor-1-alpha in multidrug resistance induced by hypoxia in HepG2 cells. J Exp Clin Cancer Res. 2005;24(4):565-74.

117. Liang Z, Wu H, Xia J, Li Y, Zhang Y, Huang K, et al. Involvement of miR-326 in chemotherapy resistance of breast cancer through modulating expression of multidrug resistance-associated protein 1. Biochem Pharmacol. 2010;79:817-24.

118. Pogribny IP, Filkowski JN, Tryndyak VP, Golubov A, Shpyleva SI, Kovalchuk O. Alterations of microRNAs and their targets are associated with acquired resistance of MCF-7 breast cancer cells to cisplatin. Int J Cancer. 2010;127(8):1785-94.

119. Qiu T, Zhou L, Wang T, Xu J, Wang J, Chen W, et al. miR-503 regulates the resistance of non-small cell lung cancer cells to cisplatin by targeting Bcl-2. Int J Mol Med. 2013;32:593-8.

120. Zhang Y, Chen X, Lian H, Liu J, Zhou B, Han S, et al. MicroRNA503 acts as a tumor suppressor in glioblastoma for multiple antitumor effects by targeting IGF-1R. Oncol Rep. 2014;31(3):144552.

121. Zhou R, Gong A-Y, Chen D, Miller RE, Eischeid AN, Chen XM. Histone deacetylases and NF-kB signaling coordinate expression of CX3CL1 in epithelial cells in response to microbial challenge by suppressing miR-424 and miR-503. PLoS One. 2013;8(5): e65153. https://doi.org/10.1371/journal.pone.0065153.

122. Li N, Zhang F, Li S, Zhou S. Epigenetic silencing of MicroRNA503 regulates FANCA expression in non-small cell lung cancer cell. Biochem Biophys Res Commun. 2014;444(4):611-6.

123. Xiao F, Zhang W, Chen L, Chen F, Xie H, Xing C, et al. MicroRNA-503 inhibits the G1/S transition by downregulating cyclin D3 and E2F3 in hepatocellular carcinoma. J Transl Med. 2013;11:195. https://doi.org/10.1186/1479-5876-11-195.

124. Forrest AR, Kanamori-Katayama M, Tomaru Y, Lassmann T, Ninomiya N, Takahashi Y, et al. Induction of microRNAs, mir155, mir-222, mir-424 and mir-503, promotes monocytic differentiation through combinatorial regulation. Leukemia. 2010;24(2):460-6.

125. Yang Y, Luo J, Zhai X, Fu Z, Tang Z, Liu L, et al. Prognostic value of phospho-Akt in patients with non-small cell lung carcinoma: a meta-analysis. Int J Cancer. 2014;135(6):1417-24.

126. Ueda H, Abbi S, Zheng C, Guan JL. Suppression of Pyk2 kinase and cellular activities by Fip200. J Cell Biol. 2000;149(2):423-30.

127. Li Z, Rana TM. Therapeutic targeting of microRNAs: current status and future challenges. Nature Reviews. 2014;13:622-38.

128. Datta RN, Krishnan S, Speiser DE, Neufeld E, Kuster N, Bodis S, Hofmann H. Magnetic nanoparticleinduced hyperthermia with appropriate payloads: Paul Ehrlich's Bmagic (nano)bullet^ for cancer theranostics?. Cancer Treat Rev. 2016;50:217-227.

129. Whitehead KA, Langer R, Anderson DG. Knocking down barriers: advances in siRNA delivery. Nat Rev Drug Discov. 2009;8: 129-38.

130. Mirzaei H, Sahebkar A, Jaafari MR, Goodarzi M, Mirzaei HR. Diagnostic and therapeutic potential of exosomes in cancer: The beginning of a new tale?. J Cell Physiol. 2017;232(12):32513260 . 
131. Haussecker D. The business of RNAi therapeutics in 2012. Mol Ther Nucleic Acids. 2012;2:e8. https://doi.org/10.1038/mtna. 2011.9.

132. Burgess P, Hutt PB, Farokhzad OC, Langer R, Minick S, Zale S. On firm ground: IP protection of therapeutic nanoparticles. Nat Biotechnol.2010;28:1267-71.
133. Zhang Y, Wang Z, Gemeinhart RA. Progress in microRNA delivery. J Control Release. 2013;172(3):962-74.

134. Gil PR, Parak WJ. Composite nanoparticles take aim at cancer. ACS Nano. 2008;2:2200-5. 